\title{
TRENDS IN INVESTMENT ACTIVITY AND ACCUMULATION OF INVESTMENT DISPROPORTIONS IN THE ECONOMY OF UKRAINE
}

\author{
Nataliia Toropchenko ${ }^{1}$, Olena Trokhymets ${ }^{2}$
}

\begin{abstract}
The purpose of this research is to determine the trends of investment activity and the peculiarities of the disparities' formation in the territorial and sectoral structure of such activity in Ukraine. Methodology. The Pearson correlation coefficient to assess the relationship between GDP dynamics and the ratio of gross capital formation in the economy has been used in the article. Considering the peculiarities of the change in the methodology of calculating GDP in Ukraine, it should be noted that GDP has been calculated according to the methodology of the 1993 SNA in the period 1996-1999; according to the methodology of the SNA 2008 in the period 2000-2013, GDP data have not considered the annexed Crimea and the temporarily occupied territories of Donetsk and Luhansk regions in the period 2014-2020. It is advisable to use data from the World Bank to estimate the share of gross capital formation (in\% of GDP), the set of which, in contrast to domestic statistics, fully covers the analyzed period. The choice for the beginning of the 1996 interval has been conditioned by the possibility of correct comparisons of data in a single currency. The source of GDP data is the State Statistics Service of Ukraine while the source of FDI data flows and stocks in Ukraine is the data of the National Bank of Ukraine (due to changes in the methodology of calculating FDI in 2018). Practical implications. The priorities of intensifying the investment support have been formulated (return of national capital to the jurisdiction of Ukraine, increase the uniformity of the territorial structure of capital investment, increase fixed capital formation to $20+\%$, stimulate investment in military technology, NBIC convergence), including investments in science, education) based on the identified problems of investment support for the development of Ukraine's economy increasing the level of protection of property rights and guarantees of preferential treatment for investments. Value/originality. The main priorities of balanced development have been formulated (increasing the level of manufacturability of industry and services, import substitution in the production of investment and consumer goods, inclusion in global value chains, balancing the interests of large capital stakeholders, reducing dependence on external security shocks (military-political conflicts, pandemics), maintaining the level of social security, restoration of disturbed natural complexes, etc.)
\end{abstract}

Key words: investment, investment activity, economy Of Ukraine, the Pearson correlation coefficient, Russia, Ukraine, conflict, balanced development, investment disproportions, national economy.

JEL Classification: E20, E22

\section{Introduction}

Development is the objective law of society's existence and its provision is the universal purpose of state policy. At the same time, the necessity of consideration the diversity of sources, drivers, historical circumstances, mechanisms of economic systems make a non-trivial problem the search for ways to achieve development purposes (also a balance of subjective interests and efforts, affordable and innovative ways to transition to the desired quality of life, volume production, competitiveness).

Nowadays it is especially acute the issue of ensuring the balanced development of Ukraine's economy. The backwardness of the technological and economic structure, the imperfection of institutions, the social burden of public spending, regional disparities because of the military-

Corresponding author:

${ }^{1}$ Limited Liability Company Technical University Metinvest Polytechnic, Ukraine.

E-mail: nataliya-tor@ukr.net

ORCID: https://orcid.org/0000-0002-6152-9843

${ }^{2}$ Classical Private University, Ukraine.

E-mail: yelena.trohim@gmail.com

ORCID: https://orcid.org/0000-0001-7587-7948 
political conflict with Russia and the coronavirus pandemic significantly worsen the initial conditions for living standards, economic growth and global competitiveness, including resources. The achievement of balanced development of the national economy requires a scientific justification for finding ways to intensify the formation of investment resources and their direction in the restoration (and further is expanded reproduction) of capital assets, increasing manufacturability and growth of national production, sustainability under these circumstances. Solving this problem requires obtaining objective data on the state of investment support for the development of Ukraine's economy first of all. So, the purpose of the research has been to determine the trends of investment activity and the peculiarities of the formation of disparities in the territorial and sectoral structure of such activity in Ukraine.

\section{Literature review}

The papers of R. Barro, O. Osiobe, and P. Rosenstein-Rodan were devoted to the issue substantiation of the essence of the development of economic systems its components and mechanisms. Emphasis on the balance of development was made in the works of such scientists as P. Kongsamunt, N. Smentina, $\mathrm{H}$. Channery and others. Ways of improving the various components of the investment mechanism of functioning and development of national economies were covered in the works of J. Mocker, M. Feldman and others.

\section{Survey methodology}

The Pearson's correlation coefficient $r\left(B B \Pi_{t}, d_{t}^{H K}\right)$ has been used to assess the relationship between GDP dynamics and the ratio of gross capital accumulation in the economy.

The Pearson's product-moment correlation coefficient was two equal data samples $\mathrm{X}$ and $\mathrm{Y}$ have been determined by the following formula:

$$
r=\frac{\sum_{i=1}^{n}\left(x_{i}-M_{x}\right) \cdot\left(y_{i}-M_{y}\right)}{\sqrt{\sum_{i=1}^{n}\left(x_{i}-M_{x}\right)^{2} \cdot \sum_{i=1}^{n}\left(y_{i}-M_{y}\right)^{2}}} ;
$$

This coefficient values have been interpreted as follows: up to 0.2 was very weak correlation; up to 0.5 - weak correlation; up to 0.7 - average correlation; up to 0.9 - high correlation; more than 0.9 - very high correlation.
The following criterion has been used to assess the statistical significance of the difference between the correlation coefficient from 0 at the confidence level of 0.95 :

$$
\mathrm{t}_{\text {emp }}=\mathrm{r} \sqrt{\frac{\mathrm{n}-2}{1-\mathrm{r}^{2}}} \geq \mathrm{t}_{\text {table }}\left(\frac{\mathrm{p}=0,05}{2} ; \mathrm{df}=\mathrm{n}-2\right) .
$$

Accordingly trusting, the confidence interval of the correlation coefficient, the share of statistically significant coefficients has been calculated as follows:

lower border: $0,5 \cdot \ln \left(\frac{1+r}{1-r}\right)-t_{n-1}^{0,05 / 2} \cdot \frac{1}{\sqrt{n-3}}$

upper border: $0,5 \cdot \ln \left(\frac{1+r}{1-r}\right)+t_{n-1}^{0,05 / 2} \cdot \frac{1}{\sqrt{n-3}}$

Considering the peculiarities of the change in the methodology of calculating GDP in Ukraine, it should be noted that GDP has been calculated according to the methodology of the 1993 SNA in the period 1996-1999; according to the methodology of the SNA 2008 in the period 2000-2013, GDP data have not considered the annexed Crimea and the temporarily occupied territories of Donetsk and Luhansk regions in the period 2014-2020. It is advisable to use data from the World Bank to estimate the share of gross capital formation (in\% of GDP), the set of which, in contrast to domestic statistics, fully covers the analyzed period. The choice for the beginning of the 1996 interval has been conditioned by the possibility of correct comparisons of data in a single currency.

Given the view that the effect of the investment may not occur immediately, this procedure is repeated with a lag of one year: $r\left(B B \Pi_{t}, d_{t-1}^{H K}\right)$.

The characteristic of the structural features of investment activities has been carried out in the following directions:

- capital investments by financing sources, transformation of their structure;

- capital investment by type of economic activity (NACE); transformation of their structure; dynamics of concentration of their structure; uneven distribution of investment flows;

- capital investments by regions, transformation of their structure, dynamics of concentration, uneven regional structure of capital investments per capita;

- the structure of the inflow of foreign investment by country of origin; transformation of structure, dynamics of concentration; structure of inflow 
of foreign investments according to NACE, transformation of structure, dynamics of concentration;

- structure of inflow of foreign investments by countries, transformation of structure, dynamics of concentration;

- structure of the inflow of foreign investment on the basis of the country of origin of offshore zones.

Estimation of structural dissimilarities between periods was done with use of the Ryabtsev index (Ryabtsev V., Chudilin G., 2011):

$$
I R=\sqrt{\frac{\sum_{k=1}^{n}\left(d_{1 k}-d_{0 k}\right)^{2}}{\sum_{k=1}^{n}\left(d_{1 k}+d_{0 k}\right)^{2}}}
$$

where: $d_{1 k}, d_{0 k}$ are time weights of each $k$ classification group.

The Ryabtsev index is sensitive to small selections and is scaled (Table 1).

Structure concentration was assessed using the Linda index. In written for three factors it is:

$$
I L=0,5 \cdot\left(\frac{d_{1}}{0,5 \cdot\left(d_{2}+d_{3}\right)}+\frac{0,5 \cdot\left(d_{1}+d_{2}\right)}{d_{3}}\right) \cdot 100,
$$

where $d_{1}, d, d_{3}$ are shares of the first, second and third factors with the highest weight in the structure.

In terms of $I L<120 \%$ the structure can be considered unconcentrated, $120 \leq I L<200 \%$ moderately concentrated, and in terms of $I L \geq 200 \%$ concentrated.

For evaluation of the non-uniformity of the flows structure and averaged (per capita) indicators, the following indicators were used:

1) non-uniformity (differentiation) coefficient:

$$
K I=\frac{\max _{k}\left(d_{k}\right)}{\min _{k}\left(d_{k}\right)}
$$

Table 1

Scale of assessment of structural distinctions by the Ryabtsev index

\begin{tabular}{|c|c|}
\hline Levels & Characteristic of structures' dissimilarity \\
\hline $0.000-0.030$ & Identity of structures \\
\hline $0.031-0.070$ & Very low level of distinction of structures \\
\hline $0.071-0.150$ & Low level of distinction of structures \\
\hline $0.151-0.300$ & Essential level of distinction of structures \\
\hline $0.301-0.500$ & Considerable level of distinction of structures \\
\hline $0.501-0.700$ & Very considerable level of distinctions of structures \\
\hline $0.701-0.900$ & Opposite type of structures \\
\hline 0.901 and more & Complete antithesis of structures \\
\hline
\end{tabular}

Source: (Ryabtsev, Chudilin, 2001)
2) disproportion coefficient:

$$
K D=\frac{\max _{k}\left(d_{k}\right)-\min _{k}\left(d_{k}\right)}{\bar{d}}
$$

where $\bar{d}$ is an average of $d_{k}$;

3) the Theil index:

$$
I T=\frac{1}{n} \sum_{k=1}^{N}\left(\frac{I_{k}}{\bar{I}} \cdot \ln \frac{I_{k}}{\bar{I}}\right)
$$

where: $n$ is a number of classification group; $I_{k}$ is an investment volume of each $k$ classification group, $\bar{I}$ is an average of investment volumes all over the groups.

At the $I T=0$ level, the regional distribution of investments is uniform, at $I T=\ln N$, all investments are concentrated in one classification group.

For evaluation of the tightness of the relationship between GDP and the volume of accumulated foreign direct investment (FDI) in Ukraine, as well as between GDP growth and the volume of annual FDI flow to Ukraine used Spearman's rank correlation:

$$
r=1-6 \frac{\sum_{k=1}^{n} \Delta^{2}}{n^{3}-n}
$$

where $\Delta$ is the difference between the two ranks of each observation.

The source of GDP data is the State Statistics Service of Ukraine, while the source of data on FDI flows and stocks in Ukraine is the data of the National Bank of Ukraine (due to the change in the methodology of FDI calculating in 2018).

\section{Findings}

Three intervals of growth fluctuations have been identified in the development of Ukraine's economy since 1996: 1999-2009 (with a shock point - the global financial crisis of 2008-2009); 2010-2015 (combination of the rise phases 


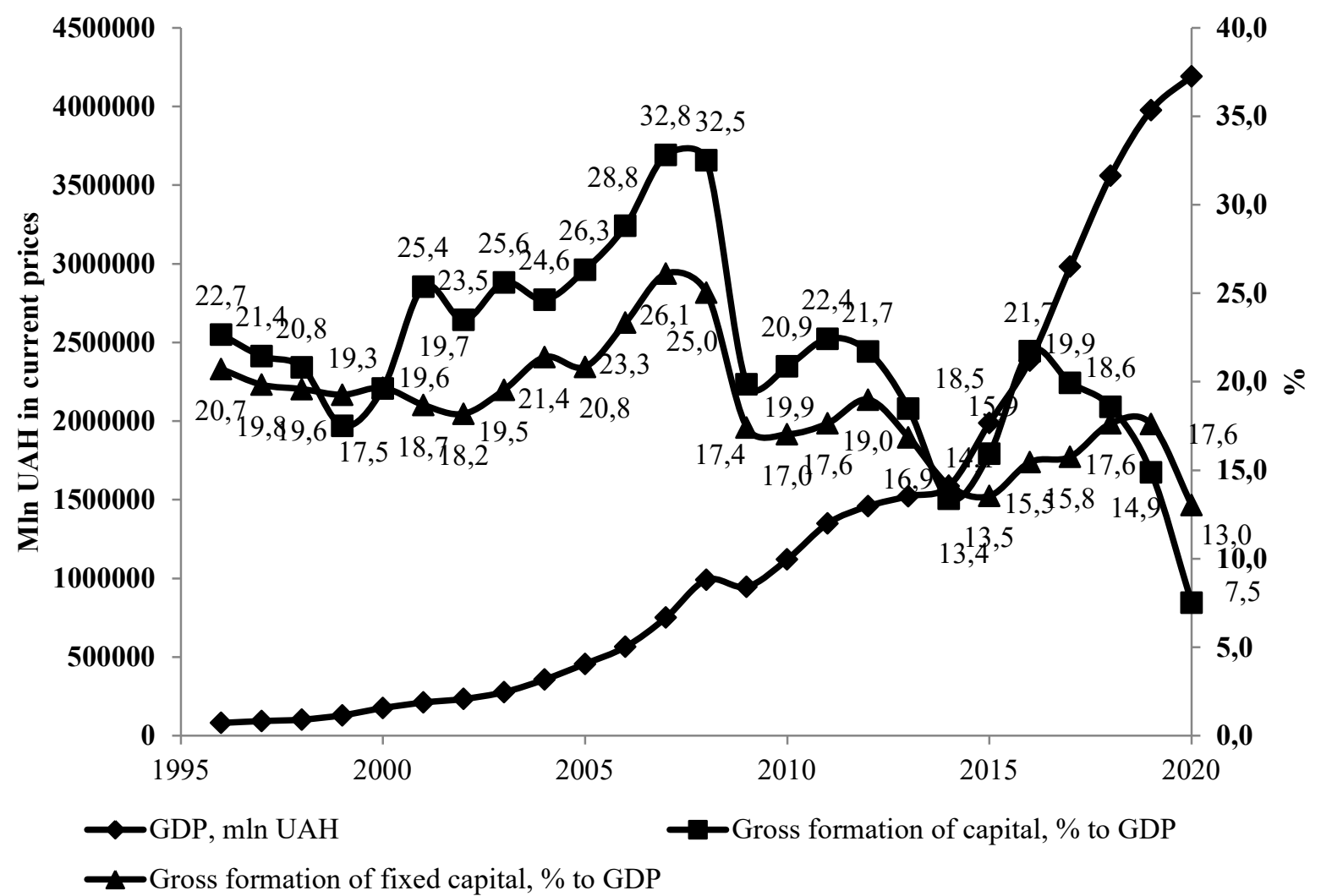

Figure 1. Dynamics of GDP and capital accumulation proportions in Ukraine, 1996-2020

Source: State Statistic Service of Ukraine, World Bank

and fall of the cycle with the point of shock and the beginning of the military-political conflict with the Russian Federation in 2014-2015); 2015-2020 (recovery in the event of a decline in the severity of the hot phase of the conflict) - Figure 1.

The Pearson's correlation assessment $(\mathrm{p} \leq 0.05)$ of the relationship between the synchronous dynamics of Ukraine's GDP and the share of gross capital formation in GDP made it possible to note the presence of a statistically significant high correlation with the indicator in the confidence interval $(0.71 ; 0.97)$ only in the first of the above periods, while the negative correlation coefficients in other periods were insignificant, indicating a lack of relationship between the analyzed indicators; approximately the same picture when determining the correlation with a lag of 1 year. So, investment resources played a significant role in economic growth only before the crisis of 2008 and then the main driving force of the dynamics of the national economy were consumption and foreign trade in raw materials (average high-tech exports in 2010-2020 was $7 \%$ of output). Besides, it was noteworthy that the level of fixed capital formation exceeded 20\% (this level is considered sufficient to maintain stable economic growth) only in the short period of 2004-2009 and further for various reasons (post-crisis pessimistic expectations national and foreign investors, the military-political conflict with the Russian Federation, the failed regulatory decisions of governments after the presidential and parliamentary elections in 2020) was rapidly declining.

The results of the assessment of structural dynamics indicators, which reflect the trends in the formation of disparities in investment activity in Ukraine, are presented in table 1.

The dynamics of these indicators have been reviewed below more objectively. The main source of capital investment in Ukraine was the own funds of the real sector of the economy till now (Table 2).

The following trends should also be noted. Firstly, the weight of public funds in capital investments increased (from $7.7 \%$ to $19.1 \%$ ) due to the beginning of the reform of administrative and financial decentralization in 2015. At the same time, these investments were important primarily for improving the infrastructure of public services (including education, health care, local development), that is they did not have significant 
Vol. 2 No. 1, 2021

Green, Blue \& Digital Economy Journal

Table 1

Indicators of assessment of structural disproportions of investment support for the development of the Ukrainian economy

\begin{tabular}{|c|c|c|c|c|c|c|c|c|c|c|c|c|}
\hline & 2010 & 2011 & 2012 & 2013 & 2014 & 2015 & 2016 & 2017 & 2018 & 2019 & 2020 & 2020 to 2010 \\
\hline \multicolumn{13}{|c|}{ The structure of sources of capital investment } \\
\hline IR & - & 0,034 & 0,018 & 0,040 & 0,042 & 0,036 & 0,028 & 0,026 & 0,019 & 0,027 & 0,033 & 0,095 \\
\hline \multicolumn{13}{|c|}{ Structure of capital investments according to NACE } \\
\hline IR & - & 0,065 & 0,086 & 0,101 & 0,040 & 0,118 & 0,104 & 0,054 & 0,072 & 0,105 & 0,102 & 0,229 \\
\hline IL & 139,0 & 145,9 & 121,7 & 137,0 & 158,4 & 137,4 & 128,6 & 130,1 & 156,7 & 139,7 & 146,7 & - \\
\hline IT & 0,328 & 0,310 & 0,314 & 0,367 & 0,406 & 0,346 & 0,336 & 0,322 & 0,315 & 0,326 & 0,300 & - \\
\hline \multicolumn{13}{|c|}{ Territorial structure of capital investments (flow) } \\
\hline IR & - & 0,057 & 0,032 & 0,041 & 0,093 & 0,059 & 0,039 & 0,033 & 0,066 & 0,025 & 0,046 & 0,086 \\
\hline IL & 289,8 & 255,6 & 271,1 & 258,2 & 264,5 & 249,5 & 261,4 & 304,7 & 359,6 & 320,5 & 349,6 & - \\
\hline IT & 0,570 & 0,611 & 0,608 & 0,576 & 0,585 & 0,598 & 0,550 & 0,549 & 0,669 & 0,671 & 0,625 & - \\
\hline \multicolumn{13}{|c|}{ Territorial structure of capital investment per capita (flow) } \\
\hline KI & 12,5 & 13,0 & 13,0 & 12,6 & 12,8 & 33,1 & 25,7 & 30,8 & 46,2 & 46,6 & 36,3 & - \\
\hline $\mathrm{KD}$ & 4,3 & 4,3 & 4,2 & 4,0 & 4,3 & 4,7 & 4,3 & 4,3 & 4,9 & 4,8 & 4,4 & - \\
\hline \multicolumn{13}{|c|}{ Territorial structure of foreign direct investment (balance) } \\
\hline IR & - & - & - & - & - & - & 0,055 & 0,030 & 0,008 & 0,055 & 0,024 & 0,050 \\
\hline IL & - & - & - & - & - & 430,6 & 536,8 & 549,6 & 230,9 & 488,8 & 486,5 & - \\
\hline IT & - & - & - & - & - & 1,126 & 1,259 & 1,277 & 1,255 & 1,115 & 1,064 & - \\
\hline \multicolumn{13}{|c|}{ Structure of foreign direct investment by NACE (aggregate, balance) } \\
\hline IR & - & - & - & - & - & - & 0,066 & 0,079 & 0,033 & 0,071 & 0,034 & 0,104 \\
\hline IL & - & - & - & - & - & 147,9 & 143,6 & 210,4 & 210,3 & 190,5 & 189,5 & - \\
\hline IT & - & - & - & - & - & 1,126 & 1,259 & 1,277 & 1,255 & 1,115 & 1,064 & - \\
\hline \multicolumn{13}{|c|}{ Structure of foreign direct investment by geographical area (balance) } \\
\hline IR & - & - & - & - & - & & 0,046 & 0,048 & 0,032 & 0,034 & 0,048 & 0,090 \\
\hline IL & - & - & - & - & - & 450,3 & 410,8 & 360,5 & 361,9 & 325,3 & 327,0 & - \\
\hline
\end{tabular}

Table 2

Structure of sources of capital investments in Ukraine, \%

\begin{tabular}{|l|c|c|c|c|c|c|c|}
\hline Sources & 2010 & 2015 & 2016 & 2017 & 2018 & 2019 & 2020 \\
\hline Total & 100,0 & 100,0 & 100,0 & 100,0 & 100,0 & 100,0 & 100,0 \\
\hline the state budget & 5,7 & 2,5 & 2,3 & 3,5 & 4,0 & 5,0 & 8,7 \\
\hline local budgets & 3,2 & 5,2 & 7,1 & 9,2 & 8,7 & 9,6 & 10,4 \\
\hline own funds of enterprises and organizations & 61,7 & 67,5 & 69,4 & 69,9 & 71,3 & 68,1 & 66,5 \\
\hline bank loans and other lending & 12,7 & 7,6 & 7,1 & 5,3 & 6,7 & 7,0 & 6,7 \\
\hline funds of non-resident investors & 2,1 & 3,0 & 2,9 & 1,4 & 0,3 & 0,6 & 0,4 \\
\hline public funds for construction of own's housing & 10,5 & 11,7 & 8,9 & 7,8 & 6,4 & 5,6 & 4,9 \\
\hline other financing sources & 4,3 & 2,4 & 2,3 & 2,9 & 2,6 & 4,1 & 2,4 \\
\hline
\end{tabular}

Source: calculated on the base of State Statistic Service of Ukraine data

productivity in the short term. Other areas of public investment were road infrastructure (state and local budgets) and defense (state budget) but they were essentially part of improving collective consumption and had an indirect effect on economic growth and, moreover, the development of the technological base of the Ukrainian economy.

Secondly, there was a decrease in the share of bank lending in the formation of development investment funds. This trend was due to a set of reasons:
- reduction of investment and credit activity of banking institutions after the crisis of 2008-2009 due to the motive of caution, increase of prudential requirements, deterioration of investment expectations related to the prospects of Ukrainian exports;

- instability of the banking system in 2014-2017 due to the loss of assets after the military-political conflict with Russia, withdrawal of foreign capital, especially Russian, general macroeconomic instability at this time and the 
policy of the National Bank of Ukraine aimed at rehabilitating the banking system;

- panic sentiment of deposit holders, etc.

Thirdly, the share of foreign investment in fixed capital decreased during the entire period of 2010-2020. This trend was based on the motives of prudence of foreign investors, a certain deterioration of investment relations with the Russian Federation, the withdrawal of capital by residents due to political changes. At the same time, the assessment of structural dynamics according to the Ryabtsev index shows that there are almost no significant changes in the structure of capital investment sources. The structure of capital investment by type of economic activity is shown in table 3.

Differences in structures compared to the previous year were observed in 2015, which was due to the growth of the share of investment in the tertiary sector (services of various kinds), 2019 - due to the growth of investment in agriculture and mining, collective consumption by reducing the share of the services and trade sector. The Linda index indicates a low and moderate level of concentration of the structure and the research of non-uniformity of flows on a branch basis - an acceptable level of nonuniformity. So, the areas of investment by industry are sufficiently diversified but the high share of investment in agriculture and extraction industry indicates a tendency to deindustrialize Ukraine's economy and its predominantly raw materials. Significant changes in investment directions under NACE are reflected in a more than twofold reduction in investment in construction and an increase in public sector investment in collective consumption infrastructure.

The regional distribution of the annual capital investment flow is highlighted in Table 4. We can see that the structure has a very significant level of concentration from data on it. The amount of investment that goes to the capital is almost a third of the total flow. The Ryabtsev Index shows that there were no significant changes in the regional structure of capital investment. The dynamics of the Linda index shows that the concentration of investment flows in the structure is growing and due to small losses in the weight of the peripheral regions (except for Dnipropetrovsk

Table 3

Structure of capital investments according to the NACE, \%*

\begin{tabular}{|l|c|c|c|c|c|c|c|}
\hline \multicolumn{1}{|c|}{ NACE sections } & 2010 & 2015 & 2016 & 2017 & 2018 & 2019 & 2020 \\
\hline Total & $\mathbf{1 0 0 , 0}$ & $\mathbf{1 0 0 , 0}$ & $\mathbf{1 0 0 , 0}$ & $\mathbf{1 0 0 , 0}$ & $\mathbf{1 0 0 , 0}$ & $\mathbf{1 0 0 , 0}$ & $\mathbf{1 0 0 , 0}$ \\
\hline Agriculture, forestry and fishing & 6,1 & 11,0 & 14,1 & 14,3 & 11,4 & 9,5 & 10,0 \\
\hline Mining and quarrying & 8,5 & 6,8 & 6,3 & 7,9 & 9,3 & 11,0 & 9,9 \\
\hline Manufacturing & 16,7 & 16,9 & 17,3 & 16,5 & 17,4 & 17,0 & 16,6 \\
\hline Electricity, gas, steam and air conditioning supply & 5,1 & 7,8 & 8,6 & 6,9 & 7,2 & 12,1 & 8,3 \\
\hline $\begin{array}{l}\text { Water supply; sewerage; waste management and } \\
\text { remediation activities }\end{array}$ & 0,4 & 0,6 & 0,6 & 0,6 & 0,6 & 0,7 & 0,7 \\
\hline Construction & 16,5 & 15,9 & 12,4 & 11,6 & 9,7 & 10,0 & 7,8 \\
\hline $\begin{array}{l}\text { Wholesale and retail trade; repair of motor } \\
\text { vehicles and motorcycles }\end{array}$ & 10,3 & 7,6 & 8,3 & 7,5 & 9,0 & 7,1 & 8,2 \\
\hline Transporting and storage & 10,7 & 6,8 & 7,0 & 8,5 & 8,7 & 7,0 & 6,9 \\
\hline Accommodation and food service activities & 0,6 & 0,5 & 0,4 & 0,5 & 0,5 & 0,5 & 0,4 \\
\hline Information and communication & 4,8 & 8,4 & 4,4 & 4,1 & 5,2 & 3,4 & 4,4 \\
\hline Financial and insurance activities & 3,2 & 2,4 & 2,1 & 1,8 & 1,8 & 1,8 & 2,4 \\
\hline Real estate activities & 5,5 & 4,4 & 5,5 & 5,0 & 4,8 & 4,5 & 3,9 \\
\hline Professional, scientific and technical activities & 2,8 & 1,5 & 1,8 & 1,8 & 1,9 & 1,9 & 2,3 \\
\hline Administrative and support service activities & 1,6 & 2,4 & 2,8 & 2,8 & 2,0 & 1,9 & 1,7 \\
\hline $\begin{array}{l}\text { Public administration and defense; compulsory } \\
\text { social security }\end{array}$ & 4,3 & 5,1 & 6,2 & 7,3 & 7,7 & 8,7 & 12,3 \\
\hline Education & 1,0 & 0,6 & 0,6 & 0,8 & 0,8 & 0,8 & 0,7 \\
\hline Human health and social work activities & 1,1 & 0,9 & 1,2 & 1,5 & 1,4 & 1,5 & 2,9 \\
\hline Arts, entertainment and recreation & 0,5 & 0,4 & 0,3 & 0,4 & 0,6 & 0,7 & 0,5 \\
\hline Other services activities & 0,4 & 0,1 & 0,1 & 0,1 & 0,1 & 0,1 & 0,1 \\
\hline
\end{tabular}

* Dark color indicates the cells with data of three most weighted economic activities of capital investments flows every year Source: calculated on the base of State Statistic Service of Ukraine data 
Table 4

Structure of capital investment by regions of Ukraine, \%*

\begin{tabular}{|c|c|c|c|c|c|c|c|}
\hline Regions & 2010 & 2015 & 2016 & 2017 & 2018 & 2019 & 2020 \\
\hline Vynnytsia & 2,0 & 2,9 & 2,4 & 2,6 & 3,1 & 2,5 & 2,7 \\
\hline Volyn & 1,0 & 2,4 & 1,8 & 1,6 & 1,5 & 2 & 1,8 \\
\hline Dnipro & 8,9 & 9,9 & 9,4 & 9,6 & 10,4 & 10,7 & 11,5 \\
\hline Donetsk $^{* *}$ & 8,3 & 2,9 & 3,3 & 3,9 & 4,7 & 4,9 & 5,2 \\
\hline Zhytomyr & 1,1 & 1,6 & 1,6 & 1,7 & 1,5 & 1,4 & 1,8 \\
\hline Zakarpattia & 1,2 & 1,5 & 1,1 & 1,3 & 1,3 & 1,5 & 1 \\
\hline Zaporizhzhia & 4,4 & 3 & 3,1 & 3,5 & 2,7 & 2,4 & 3,1 \\
\hline Ivano-Frankivsk & 2,4 & 3,8 & 2 & 2,2 & 1,6 & 1,5 & 1,2 \\
\hline Kyiv & 6,3 & 9,5 & 9,5 & 7,7 & 7 & 8,1 & 6,4 \\
\hline Kirovohrad & 1,2 & 1,6 & 1,9 & 1,6 & 1,2 & 1,2 & 1,3 \\
\hline Luhansk $^{* *}$ & 3,1 & 0,8 & 0,9 & 0,7 & 0,6 & 0,5 & 0,6 \\
\hline Lviv & 4,9 & 5,1 & 5,2 & 5,4 & 5 & 5 & 4,7 \\
\hline Mykolaiv & 2,4 & 2,3 & 2,8 & 2,5 & 1,7 & 2 & 1,9 \\
\hline Odesa & 5,4 & 3,9 & 4,6 & 5 & 4,1 & 3,4 & 4,2 \\
\hline Poltava & 3,5 & 3,2 & 3,4 & 3,5 & 3,2 & 3,7 & 5 \\
\hline Rivne & 1,1 & 1,7 & 1,3 & 1,4 & 1,3 & 1,1 & 1,1 \\
\hline Sumy & 1,2 & 1,4 & 1,6 & 1,6 & 1,3 & 1,2 & 1,4 \\
\hline Ternopil & 1,2 & 1,5 & 1,4 & 1,6 & 1,5 & 1,5 & 1,4 \\
\hline Kharkiv & 4,5 & 4,2 & 4,8 & 4,3 & 4,1 & 3,7 & 4 \\
\hline Kherson & 1,0 & 1,2 & 1,3 & 1,6 & 1,5 & 2 & 1,4 \\
\hline Khmelnytskyi & 1,6 & 2,7 & 2,7 & 2,3 & 2 & 1,7 & 2,1 \\
\hline Cherkassy & 1,6 & 1,7 & 1,9 & 1,8 & 1,9 & 1,8 & 1,8 \\
\hline Chernivtsi & 0,9 & 1,1 & 0,7 & 0,7 & 0,6 & 0,6 & 0,7 \\
\hline Chernyhiv & 1,0 & 1,4 & 1,6 & 1,6 & 1,6 & 1,4 & 1,6 \\
\hline Kyiv-capital city & 29,8 & 28,7 & 29,7 & 30,3 & 34,6 & 34,2 & 32,1 \\
\hline
\end{tabular}

* Dark color indicates the cells with data of three most weighted regions of capital investments flows every year

** Only territories controlled by Ukrainian government

Source: calculated on the base of State Statistic Service of Ukraine data

region). It should also be noted that Donetsk and Dnipropetrovsk regions competed for the second and third places with the advantage of the first in the period up to 2014. But the conflict in eastern Ukraine, which began in 2014 first of all, led to loss of control over some territories disposed assets and secondly, lost assets had significant production and financial weight. The dynamics of the Tail index for per capita investment in the regions is additional evidence in favor of growing inequality between regions on the basis of the distribution of capital investment.

The Spearman's rank correlation assessment between GDP and accumulated FDI in Ukraine has showed a statistically significant $(\mathrm{p} \leq 0.05)$ direct medium-strength relationship $(\mathrm{r}=0.69)$ and no statistically significant relationship between GDP growth and the volume of annual FDI flow to Ukraine. At the same time, the weakening of communication is due to the trends of 2010-2020.
The geographical structure of FDI donors in aggregate form is presented in table 5 .

The geographical structure of FDI indicates a high level of danger. It is excessively concentrated (Linda's index in 2015 was 450.3, in 2020 - 327.0) because the main investors in Ukraine are Cyprus (average 31.4\%) and the Netherlands (20.4\%). They are offshore zones according to the IMF. In general, in 2020 the share of FDI originating from offshore zones was about $63 \%$.

The main recipients of FDI were processing industry on the basis of economic activities (Table 6). There were low-tech primarily (average share in the accumulated volume of FDI in 2015-2020 was 23.7\%), wholesale and retail trade $(15.1 \%)$, financial and insurance activities $(10.8 \%)$ and the extractive industry in recent years.

It should be noted that the average level of FDI in this period (the residents of Ukraine (Roundtripping) are the final controllers of them) was 
Table 5

Structure of FDI stocks be donors aggregated, \%

\begin{tabular}{|l|c|c|c|c|c|c|}
\hline Part of the World & 2015 & 2016 & 2017 & 2018 & 2019 & 2020 \\
\hline Europe & 83,3 & 82,4 & 83,3 & 84,6 & 86,9 & 86,1 \\
\hline Asia & 2,1 & 2,8 & 2,8 & 3,0 & 3,0 & 3,6 \\
\hline Americas & 8,1 & 8,1 & 7,1 & 5,8 & 4,4 & 4,2 \\
\hline Africa & 0,0 & 0,1 & 0,1 & 0,1 & 0,2 & 0,1 \\
\hline Australia and Oceania & 0,1 & 0,1 & 0,1 & 0,1 & 0,1 & 0,1 \\
\hline Non distributed & 6,3 & 6,5 & 6,5 & 6,3 & 5,5 & 5,9 \\
\hline
\end{tabular}

Source: calculated on the base of National Bank of Ukraine data

Table 6

Structure of FDI stocks according to the NACE, \%*

\begin{tabular}{|l|c|c|c|c|c|c|}
\hline \multicolumn{1}{|c|}{ NACE sections } & 2015 & 2016 & 2017 & 2018 & 2019 & 2020 \\
\hline Total & $\mathbf{1 0 0 , 0}$ & $\mathbf{1 0 0 , 0}$ & $\mathbf{1 0 0 , 0}$ & $\mathbf{1 0 0 , 0}$ & $\mathbf{1 0 0 , 0}$ & $\mathbf{1 0 0 , 0}$ \\
\hline Agriculture, forestry and fishing & 4,8 & 1,7 & 2,1 & 2,2 & 1,5 & 1,9 \\
\hline Mining and quarrying & 8,1 & 6,9 & 6,8 & 7,7 & 10,1 & 9,7 \\
\hline Manufacturing & 22,4 & 22,4 & 25,3 & 25,8 & 23,6 & 22,9 \\
\hline Electricity, gas, steam and air conditioning supply & 4,0 & 2,6 & 3,6 & 4,2 & 7,0 & 7,3 \\
\hline $\begin{array}{l}\text { Water supply; sewerage; waste management and } \\
\text { remediation activities }\end{array}$ & 0,1 & 0,1 & 0,2 & 0,1 & 0,1 & 0,1 \\
\hline Construction & 2,3 & 2,6 & 2,5 & 2,0 & 1,7 & 2,0 \\
\hline $\begin{array}{l}\text { Wholesale and retail trade; repair of motor vehicles } \\
\text { and motorcycles }\end{array}$ & 15,0 & 15,5 & 15,3 & 14,6 & 14,3 & 15,9 \\
\hline Transporting and storage & 3,3 & 3,4 & 3,7 & 3,4 & 3,9 & 3,5 \\
\hline Accommodation and food service activities & 0,6 & 0,7 & 0,7 & 0,7 & 0,6 & 0,5 \\
\hline Information and communication & 5,8 & 6,4 & 6,7 & 6,1 & 5,8 & 6,0 \\
\hline Financial and insurance activities & 13,5 & 14,0 & 9,4 & 8,9 & 10,1 & 9,2 \\
\hline Real estate activities & 6,6 & 8,9 & 8,7 & 9,7 & 9,2 & 9,2 \\
\hline Professional, scientific and technical activities & 4,2 & 5,4 & 5,4 & 4,3 & 4,4 & 3,6 \\
\hline Administrative and support service activities & 2,7 & 2,9 & 3,2 & 3,6 & 1,7 & 1,7 \\
\hline Education & 0,0 & 0,1 & 0,1 & 0,0 & 0,0 & 0,0 \\
\hline Human health and social work activities & 0,2 & 0,1 & 0,2 & 0,1 & 0,2 & 0,3 \\
\hline Arts, entertainment and recreation & 0,4 & 0,3 & 0,3 & 0,3 & 0,3 & 0,3 \\
\hline Non distributed & 5,9 & 5,9 & 6,0 & 6,2 & 5,4 & 5,8 \\
\hline
\end{tabular}

* Dark color indicates the cells with data of three most weighted economic activities in FDI stocks every year

$24 \%$, in particular, in the sector of non-financial corporations was $27 \%$. It should explain the investment in the modernization of mining assets of the largest integrated corporate structures in Ukraine. The level of the structure concentration was high in 2017-2018, but later the Linda index was in the range of moderate concentration values. The significant structural changes in the dynamics have not been noted.

Similar (as in capital investments) centers of gravity have been identified in the regional aspect of FDI inflows but with a higher degree of concentration and unevenness.

\section{Conclusions}

Insufficient investment funds to ensure growth due to the constant decline in the share of the secondary sector since 2000, unstable and low levels of gross national savings (in $2019-7 \%$ ), catastrophically low level of market capitalization of national companies (2019-3.4\%), as well as the fact that the average share of gross fixed capital formation in GDP for the period 1996-2020 was $18.7 \%$. And only in 2004-2008 its value exceeded $20 \%$. The sectoral structure of capital investment and FDI does not meet competitive challenges, the share of high-tech production and exports is low, 
and there are significant disparities in the territorial structure between the center and the regions.

So, due to the problems of investment support for the development of Ukraine's economy were formulated the main priorities of sustainable development in the research (increasing the level of manufacturability of industry and services, import substitution in the production of investment and consumer goods, inclusion in global value chains, balanced interests of stakeholders security shocks (military-political conflicts, pandemics), maintaining the level of social security, restoration of disturbed natural complexes, etc.) and priorities for intensifying investment support (return of national capital to the jurisdiction of Ukraine, increasing the uniformity of the territorial structure of capital investment, increasing fixed capital formation to $20+\%$, stimulation of investments in military technologies, NBIC-convergence (including investments in science, education), increasing the level of protection of property rights and guarantees of preferential regimes for investments and so on.

\section{References:}

Riabtseva, V., \& Chudilina, G. (2001). Regional statistics: Textbook. Moscow: MID, 380 p.

Linda, R. (1976). Methodology of concentration analysis applied to the study of industries and markets, Commission of the European Communities. Brussels, 156 p. Retrieved December 15, 2020, from: https://core.ac.uk/download/pdf/5091475.pdf

Theil, H. (1967). Economics and Information Theory. Journal Article. North-Holland, vol. 18, no. 3, 328 p. DOI: https://doi.org/10.2307/3006993

Feldman, Maryann \& Hadjimichael, Theodora \& Kemeny, Thomas \& Lanahan, Lauren (2014). The logic of economic development: A definition and model for investment. Environment and Planning C Government and Policy, 34. DOI: https://doi.org/10.1177/0263774X15614653

Chenery, H. (1979). Structural Change and Development Policy. Oxford University Press: Oxford and New York. Chenery H., Robinson S. and Syrquin M. (eds) (1986). Industrialization and Growth: A Comparative Study. Oxford University Press: Oxford and New York.

Kongsamunt P., Rebelo S. and Xie D. (2001). Beyond balanced growth. Review of Economic Studies, 68(4): 869-882.

Barro, Robert J., and Xavier Sala-i-Martin (1995). Economic Growth. New York: McGraw-Hill.

Barro, Robert J. (2001). Human capital and growth. American Economic Review, 91: 12-17. [CrossRef] Hanushek, Eric A. (2013). Economic growth in developing countries: The role of human capital. Economics of Education Review, 37: 204-12.

Mokyr, Joel (2018). The past and the future of innovation: Some lessons from economic history. Explorations in Economic History, 69: 13-26.

Osiobe, Ejiro U. (2019). A Literature Review of Human Capital and Economic Growth. Business and Economic Research, 9: 179-96.

Rosenstein-Rodan, Paul N. (1934). “The Rôle of Time in Economic Theory.” Economica N.S., 1(1):77-97. Rosenstein-Rodan, Paul N., ed. (1964b). Capital Formation and Economic Development. Cambridge: MIT Press.

State Statistics Service of Ukraine: Statistical Information. Retrieved February 15, 2021 from: http://www.ukrstat.gov.ua/

Statistical classification of economic activites in the European Community (NACE Rev. 2). World Bank Databank. Retrieved February 18, 2021 from: https://ec.europa.eu/eurostat/ documents/3859598/5902521/KS-RA-07-015-EN.PDF

National Bank of Ukraine: External Sector Statistics. Retrieved December 18, 2020 from: https://bank.gov.ua/ua/statistic/sector-external/data-sector-external

World Bank Databank. Retrieved December 18, 2020 from: https://databank.worldbank.org/home.aspx 